\title{
DESAIN BATIK , BRAND IMAGE , DAN BUDAYA KONSUMEN TERHADAP KEPUTUSAN PEMBELIAN PADA ETHNIC BATIK DAN CRAFT KLATEN JAWA TENGAH
}

\author{
Yesi Ade Pratiwi ${ }^{1)}$, Ida Aryati ${ }^{2}$, Burhanudin AY ${ }^{3)}$ \\ Fakultas Ekonomi Manajemen Universitas Islam Batik Surakarta ${ }^{12) 3)}$ \\ E-mail : yesiade04@gmail.com ${ }^{1)}$
}

\begin{abstract}
The purpose analyze the effect of either simultaneously and partal batik designs, brand image, and consumer culture on purchasing decisions on Ethnic batik and Craft in Klaten, Central Java. The type of descriptive is quantitative. Population is Ethnic batik consumers and Craft Klaten who make transactions. The sample is 100 consumers. Data obtained from questionnaires with accidental sampling sampling techniques. F test results prove that batik design, brand image, and consumer culture simultaneously influence purchasing decisions on Ethnic Batik and Craft Klaten in Central Java, where the value of Fcount $=27,027>$ Ftable $=$ 2.70 with a significance value of $0.000<0.05$. The results of the t test prove positive and significant batik design effect on Ethnic batik and Craft Klaten with tcount $=2.703>1.985$ significant value $0.008<0.05$. Brand image have a positive and significantly effect influential decisions on Ethnic batik and Craft Klaten with tcount $=2.714>1.985$ and significant $0.008<0.05$. Consumer culture have a positive and significantly influential decisions on Ethnic batik and Craft Klaten with tcount $=2.814>1.985$ and significant $0.006<0.05$.
\end{abstract}

\section{Keywords: batik design, brand image, consumer culture}

\section{PENDAHULUAN}

Berkembangnya zaman dan kebutuhan sandang yang semakin meningkat, membuat iklim usaha di dunia fashion semakin meningkat (Soewito Yudhi, 2013). Pertumbuhan dalam dunia pasar saat ini membuat persaingan pada industri batik semakin tinggi. Persaingan pasar menuntut para indutri batik agar selalu menginovasi produknya dengan strategi bisnis yang mereka gunakan untuk meningkatkan laba penjualan dan dengan tujuan agar masyarakat menggunakan batik.

Desain batik sering kali menjadi factor yang mempengaruhi penampilan seseorang dan menjadi pertimbangan dalam pembelian. (Saraswati, Pradhanawati, \& Hidayat, 2013). Bagian yang dapat dikenali namun tidak dapat diucapkan dan dapat dibangun secara terus menerus melalui iklan dan media massa dengan tema yang berinovasi, merupakan penjabaran dari brand image, (Ummah dan Sastika, 2016). Gaya hidup yang berkembang dalam masyarakat yang menjadi kebiasan dan terus menerus di jalankan merupakan budaya konsumen. (Santoso \& Purwanti, 2013). Tindakan yang dilakukan konsumen yang melibatkan pilihan diantara dua atau lebih produk untuk melakukan pembelian merupakan penjabaran keputusan pembelian. (Santoso \& Purwanti, 2013).

Ethnic Batik dan Craft sebuah produsen dan pengrajin batik yang beralamatkan di Jl.Raya 
Klaten Sol o Km 3 No 30, Belang Wetan, Klaten, Jawa Tengah, berdiri sejak tahun 2001, memberikan warna baru dalam dunia batik di Indonesia dengan motif dan warna-warna cerah, dengan desain kontemporer. Sehingga setiap helai kain batik yang dibuat memiliki sentuhan khusus dari canting tangan yang berbeda beda dengan metode kreking atau kebatikan

Sejak tahun 2003 Ethnic Batik dan Craft sudah mengekspor produk ke beberapa negara misalnya Spanyol, Belanda, Italia, Malaysia, Afrika dan lain-lain. Di Ethnic Batik dan Craft selalu berinovasi dengan design baru dan limited design karena motif yang digunakan terbatas, satu motif hanya satu produksi yang di produksi dengan jumlah terbatas. Desain baju dari yang klasik hingga modern disesuaikan dengan budaya konsumen atau permintaan konsumen yang sedang trend saat ini.

Dari uraian tersebut, penulis berpendapat layak untuk melakukan penelitian dengan judul desain batik, brand image, dan budaya konsumen terhadap keputusan pembelian pada ethnic batik dan craft Klaten Jawa Tengah.

\section{LANDASAN TEORI}

Pengambilan keputusan oleh konsumen guna menentukan pembelian suatu produk yang beragam melalui pertimbangan produk dinamakan keputusan pembelian (Harahap, 2015).

Kerangka gambar pada suatu kain yang bermaknakan ide, gagasan, dan perasaan seseorang yang dituangkan dalam sebuah kain dinamakan desain batik. Desain batik disebut juga corak batik atau pola batik atau motif batik. (Poon T.F Stephen, 2017).

Pemikiran atau persepsi konsumen tehadap lambang, symbol, nama dan lain sebagainya yang menunjukkan suatu produk tersebut merupakann citra merek (brand image). Abdillah et all, (2016).

Istilah yang menyangkut tidak hanya perilaku konsumsi seseorang tetapi adanya suatu proses kegiatan yang dilakukan berulang dan menjadi kebiasaan dalam masyarakat dinamakan budaya konsumen,

\section{KERANGKA PEMIKIRAN}

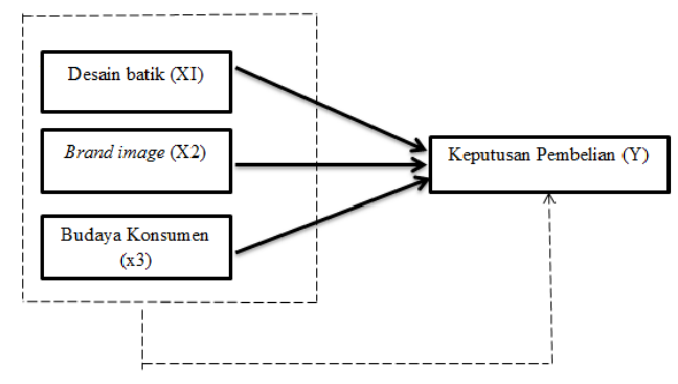




\section{HIPOTESIS}

H1: Diduga desain batik, brand image, dan budaya konsumen berpengaruh simulltan dan signifikan terhadap keputusan pembelian pada ethnic batik dan craft batik Klaten Jawa Tengah

H2: Diduga desain batik berpengaruh secara positif dan signifikan terhadap keputusan pembelian pada ethnic batik dan craft Klaten Jawa Tengah

H3: Diduga brand image berpengaruh secara positif dan signifikan terhadap keputusan pembelian pada ethnic batik dan craft Klaten Jawa Tengah.

H4: Diduga budaya konsumen berpengaruh secara positif dan signifikan terhadap keputusan pembelian pada ethnic dan craft batik Klaten Jawa Tengah.

\section{METODE PENELITIAN}

Jenis peneltian kuantitatif. populasinya yaitu konsumen Ethnic batik dan Craft Klaten, dengan sampel 100 responden. Data diperoleh dari kuesioner dengan teknik pengambilan sampel accidental sampling. Teknik analisis data pada penelitian yaitu uji asumsi klasik, regresi linier berganda, uji F, uji t, $\mathrm{R}^{2}$.

\section{HASIL DAN PEMBAHASAN}

\section{Uji Asumsi Klasik}

1) Uji Normalitas

\begin{tabular}{ccc} 
& $\begin{array}{c}\text { Hasil Uji Normalitas } \\
\text { One-Sample Kolmogrov-Smirnov Test }\end{array}$ \\
\hline \multicolumn{4}{c}{ Unstandarized Residual } & Keterangan \\
\hline$N$ & 100 & \\
Kolmogrov-Smimov Z & .945 & Data terdistribusi normal \\
asymp.Sig 92 tailed) & .334 & \\
\hline
\end{tabular}

Uji normalitas memiliki sebaran data yang normal. Hasil pengujian Kolmogrov-Smirnov-Test, nilai p-value $(0,334>0,05)$. 
2) Uji Multikolinearitas

\begin{tabular}{|c|c|c|c|}
\hline \multicolumn{4}{|c|}{$\begin{array}{c}\text { Hasil Uji Multikolonieritas } \\
\text { Coefficients }\end{array}$} \\
\hline Model & $\begin{array}{l}\text { Collinearity } \\
\text { Tolerance }\end{array}$ & $\begin{array}{l}\text { Statistics } \\
\text { VIF }\end{array}$ & Ketrangan \\
\hline Desain Batik & .499 & 2.005 & $\begin{array}{l}\text { Tidak terjadi } \\
\text { multikolinearitas }\end{array}$ \\
\hline Brand Image & .493 & 2.028 & $\begin{array}{l}\text { Tidak terjadi } \\
\text { multikolinearitas }\end{array}$ \\
\hline $\begin{array}{l}\text { Budaya } \\
\text { Konsumen }\end{array}$ & .785 & 1.273 & $\begin{array}{l}\text { Tidak terjadi } \\
\text { multikolinearitas }\end{array}$ \\
\hline
\end{tabular}

Uji multikolinearitas menunjukan model regresi pada penelitian ini tidak terjadi multikolinearitas. Diperoleh dari tolerance value $>0,10$ pada VIF kurang dari 10.

3) Uji Heteroskedastisitas

Hasil Uji heteroskedastisitas

\begin{tabular}{llc}
\hline \multicolumn{1}{c}{ Model } & Sig & \multicolumn{1}{c}{ Keterangan } \\
\hline $\begin{array}{l}\text { Desain Batik } \\
\text { Brand Image }\end{array}$ & .113 & Tidak terjadi heterokedastisitas \\
$\begin{array}{l}\text { Budaya } \\
\text { konsumen }\end{array}$ & .064 & Tidak terjadi heterokedastisitas \\
\hline
\end{tabular}

Uji Glejser membuktikan model regresi tidak terjadi heteroskedatisitas dan nilai probabilitas signifikansi pada variabel independen lebih dari $5 \%$.

\section{Uji Regresi Linier Berganda}

\begin{tabular}{|c|c|c|}
\hline \multicolumn{3}{|c|}{ Analisis Regresi Linier Berganda } \\
\hline Model & B & $\begin{array}{r}\text { Unstandardized Coefficients } \\
\text { Std. Error }\end{array}$ \\
\hline 1. (Constant) & 7.174 & 1.744 \\
\hline Desain Batik & .213 & .079 \\
\hline Brand Image & .238 & .088 \\
\hline $\begin{array}{l}\text { Budaya } \\
\text { Konsumen }\end{array}$ & .230 & .082 \\
\hline
\end{tabular}

$\mathrm{Y}=7,174+0,213 \mathrm{X}_{\mathrm{D}}+0,238_{\mathrm{XB}}+0,230 \mathrm{X}_{\mathrm{BK}}+\mathrm{e}$

Keterangan:

a. Nilai konstanta (a) sebesar 7.174 artinya variabel desain batik, brand image, dan budaya konsumen secara positif berpengaruh terhadap keputusan pembelian sebesar 7.174.

b.. Koefisien variable desain batik $\left(b_{1}=0,213\right.$. Artinya, desain batik meningkat satu satuan, 
variabel lain tetap, maka variable keputusan pembelian naik 0,213.

c. Koefisien variabel brand image $\left(\mathrm{b}_{2}\right)=0,238$. Artinya, brand image naik satu satuan, variable lain tetap, maka keputusan pembelian naik 0,238.

d. . Koefisien variabel budaya konsumen $\left(b_{3}\right)=0,230$. Artinya, apabila budaya konsumen naik satu satuan, variable lain tetap, maka keputusan pembelian naik 0,230.

\section{Uji F}

Uji yang digunakan mengetahui pengaruh desain batik, brand image, dan budaya konsumen terhadap keputusan pembelian pada Ethnic batik dan Craft Klaten (uji simultan).

Nilai $F_{\text {hitung }}>F_{\text {tabel }}(27.027>$

2,70) dan signifikansi $0,000<$

0,05 artinya desain batik, brand image, dan budaya konsumen berpengaruh secara simultan dan signifikan terhadap keputusan pembelian pada Ethnic batik dan Craft Klaten

\section{Uji t}

Uji yang digunakan mengetahui seberapa besar variabel Y memilik pengaruh terhadap variabel $X$. Hasil analisis data yaitu:

1) Desain Batik

Nilai $t_{\text {tabel }}<t_{\text {hitung }}(1,985<2.703)$ nilai signifikan $0,008<0,05$ dapat disimpulkan desain batik berpengaruh secara positif dan signifikan terhadap keputusan pembelian Ethnic batik dan Craft Klaten.

2) Brand Image

Nilai $\mathrm{t}_{\text {tabel }}<\mathrm{t}_{\text {hitung }}(1,985<2.714)$ nilai signifikan $0,008<0,05$ dapat disimpulkan brand image berpengaruh secara positif dan signifikan terhadap keputusan pembelian Ethnic batik dan Craft Klaten

3) Budaya Konsumen

Nilai $t_{\text {tabel }}<t_{\text {hitung }}(1,985<2.814)$ nilai signifikan $0,006<0,05$ dapat disimpulkan budaya konsumen berpengaruh secara positif dan signifikan terhadap keputusan pembelian Ethnic batik dan Craft Klaten.

\section{$\mathbf{U j i}^{2}$}

Nilai $\left(\mathrm{R}^{2}\right)$ 54,8\%. Artinya determinasi atau sumbangan variabel desain batik, brand image, dan budaya konsumen terhadap keputusan pembelian pada Ethnic batik dan Craft Klaten sebesar $54,8 \%$. Sisanya sebesar $45,2 \%$ disumbang oleh variabel lain.

\section{PEMBAHASAN}

Dari uji F membuktikan bahwa secara simultan desain batik, brand image, dan budaya konsumen berpengaruh signifikan terhadap keputusan pembelian pada Ethnic Batik dan Craft Klaten $F_{\text {hitung }}>F_{\text {tabel }}(27,027>2,70)$ dan signifikansi $0,000<5 \%$. Membuktikan semakin tinggi desain batik, bland image, dan budaya konsumen meningkatkan keputusan pembelian. 
Uji t membuktikan bahwa secara parsial desain batik berpengaruh signifikan terhadap keputusan pembelian pada Ethnic

Batik dan Craft Klaten diperoleh $t_{\text {tabel }}<t_{\text {hitung }}(1,985<2,703)$, nilai signifikansi $0,008<5 \%$ dan koefisien regresi meiliki nilai positif sebesar 0,213. Membuktikan jika desain batik yang ada dibuat semakin bagus dan inovatif akan meningkatkan keputusa pembelian. Penelitian ini sejalan dengan penelitian sebelumnya (Hidayat dkk, 2013)

Desain batik memiliki pengaruh yang besar terhadap keputusan pembelian pada Ethnic batik dan Craft Klaten karena desain dibuat menggunakan teknik kreking atau kebatikan dimana setiap helai kain dibuat dengan teliti dan bahan alami. Adanya desain kontemporer produk dan modifikasi produk membuat produk banyak diminati konsumen.

Uji t menunjukan bahwa secara parsial btand image berpengaruh signifikan terhadap keputusan pembelian pada Ethnic Batik dan Craft Klaten diperoleh $t_{\text {tabel }}<t_{\text {hitung }}(1,985<2,714)$, nilai signifikansi $0,008<5 \%$ dan koefisien regresi meiliki nilai positif sebesar 0,238 . Membuktikan jika brand image produk semakin bagus akan meningkatkan keputusan pembelian. Citra yang dimiliki produk berupa Ethnic dimana merupakan sebuah nama yang melambangkan kearifan local sebuah daerah dan meiliki nilai budaya tinggi. Penelitian ini sejalan dengan penelitian sebelumnya (Ambarini dkk. 2016).

Uji t membuktikan bahwa secara persial budaya konsumen berpengaruh signifikan terhadap keputusan pembelian pada Ethnic Batik dan Craft Klaten diperoleh $t_{\text {tabel }}<t_{\text {hitung }}(1,985<2,814)$, nilai signifikansi $0,006<5 \%$ dan koefisien regresi meiliki nilai positif sebesar 0,230. Membuktikan jika budaya konsumen yang tinggi akan meningkatkan keputusan pembelian. Penelitian ini sejalan dengan penelitian ,(Tuncel dkk,2013).

Faktor gaya hidup konsumen yang ingin menggunkan batik sesuai perkembangan zaman yaitu batik modern dengan berbagai model. Konsumen merasa percaya diri jika menggunakan batik kontemporer karena hal itu merupakan kebutuhan psikologis yang sesuai dengan konsep dirinya.

\section{KESIMPULAN}

a. Desain batik, brand image, dan budaya konsumen berpngaruh secara simutlan dan signifkan pada keputusan pembelian pada Ethnic batik dan Craft Klaten.

b. Secara positif dan signifikan desain batik berpengaruh pada keputusan pembelian pada Ethnic batik dan Craft Klaten.

c. Secara positif dan signifikan Brand image berpengaruh pada keputusan pembelian pada Ethnic batik dan Craft Klaten.

d. Secara positif dan signifikan Budaya konsumen berpengaruh pada keputusan pembelian pada Ethnic batik dan Craft Klaten.

\section{Saran}

a. Sebaiknya Ethnic batik dan Craft Klaten terus menciptakan dan mengembangkan desain yang lebih menarik lagi sesuai dengan persaingan model yang terjadi saat ini. Seperti 
memodifikasi bukan hanya dengan lurik saja tapi batik tenun yang beranekaragam.

b. Pemilik disarankan terus meningkatkan dan mempertahankan citra merek Ethnic batik dan Craft Klaten sebagai showroom batik yang memiliki produk kearifan lokal yang berkualtas tinggi, karena citra merek terbukti mampu menajdi patokan konsumen dalam melakukan pembelian.

c. Sebaiknya pemilik lebih memahami bagaimana gaya hidup konsumen sekarang yang cenderung meniru gaya berpakaian yang sesuai dengan trend yang sedang ada. Sehingga pemilik bisa memenuhi keinginan konsumen sesuai kebutuhan dan konsep diri yang diinginkan.

\section{DAFTAR PUSTAKA}

Poon, S. T. F. (2017). The Journey to 2454- 7654.0301006 Revival: Thriving Revolutionary Batik Design and Its Potential in Contemporary Lifestyle and Fashion. International Journal of History and Cultural Studies, 3(1), 48-59. https://doi.org/10.20431

Populasi, A., Cell, R., Jember, M., Cell, R., Jember, M., Samsung, S., ... Jember, m. (2016). analisis pengaruh citra merek terhadap keputusan komplek mutiara jembe.

Practices, C. P., Firat, A., Kutucuo, K., \& Saltik, A. (2013). Consumption, Consumer Culture and Consumer Society. Jurnalul Practicilor Comunitare Pozitive,

Prod, P. K., N., Manado, W. (2017). Pengaruh Kualitas Produk, Harga, Promosi pada Keputusan Pembelian Mobil Nissan X-Trail Pada Pt. Wahana Wirawan

Santoso, D. T. T., \& Purwanti, E. (2013). Pengaruh Faktor Budaya, Faktor Sosial, Faktor Pribadi, Dan Faktor Psikologis Terhadap Keputusan Pembelian Konsumen Dalam Memilih Produk Operator Seluler Indosat- M3 Di Kecamatan Pringapus Kab. Semarang. 6(12), $112-129$.

Saraswati, M. L., Pradhanawati, A., \& Hidayat, W. (2013). pengaruh desain produk, kualitas produk, dan harga terhadap keputusan pembelian pada kampung batik wiradesa, kabupaten pekalongan.

Soewito, Yudhi. 2013. Kualitas Produk, Merek dan Desain Pengaruhnya Terhadap Keputusan Pembelian.

https://doi.org/10.1017/CBO9781107415324.004 